\title{
Mechanitis polymnia casabranca AND Ithomia lichyi lichyi (LEPIDOPTERA: NYMPHALIDAE) DAMAGING TREE OF Solanum granuloso-leprosum (SOLANACEAE)
}

\author{
Wagner de Souza Tavares ${ }^{1 *}$, Alexandre Igor de Azevedo Pereira ${ }^{2}$, Olaf Hermann Hendrik Mielke ${ }^{3}$, José Eduardo \\ Serrão ${ }^{1}$, José Cola Zanuncio ${ }^{1}$
}

*Autor para correspondência: wagner.tavares@ufv.br

\begin{abstract}
The Zona da Mata region is located in southeastern Minas Gerais State, Brazil with fauna and flora diversified, including herbivorous insects and Solanaceae plants. Ithomiinae caterpillars were observed damaging tree of Solanum granulosoleprosum Dunal (Solanaceae), used for different purposes and abundant in secondary forest. The objective of this study was to identify defoliating caterpillars of S. granuloso-leprosum at the campus of Universidade Federal de Viçosa (UFV) in Viçosa, Minas Gerais State, Brazil and review host plants of Mechanitis polymnia L., 1758 (Lepidoptera: Nymphalidae). Thirteen caterpillars found damaging a tree of S. granuloso-leprosum at the campus of UFV were collected and maintained in the Laboratório de Controle Biológico de Insetos (LCBI) from UFV until adult emergence. These caterpillars were of two species, being ten of the first and three of the second species. Adult specimens of the latter species were identified as Ithomia lichyi lichyi D'Almeida, 1939 (Lepidoptera: Nymphalidae) in the Departamento de Zoologia of Universidade Federal do Paraná (UFPR) in Curitiba, Paraná State, Brazil and of the group of ten caterpillars as Mechanitis polymnia casabranca Haensch, 1905 (Lepidoptera: Nymphalidae) in the Museu de Zoologia of Universidade de São Paulo (USP) in São Paulo State, Brazil. This is the first report of M. polymnia casabranca and I. lichyi lichyi together damaging plant of S. granuloso-leprosum in the Zona da Mata region of Minas Gerais State, Brazil and 57 plants are recorded as host of $M$. polymnia.
\end{abstract}

Key words: Damage, Ithomiinae, Papilionoidea, Solanales, Zona da Mata.

\section{Mechanitis polymnia casabranca E Ithomia lichyi lichyi (LEPIDOPTERA: NYMPHALIDAE) DANIFICANDO ÁRVORE DE Solanum granuloso-leprosum (SOLANACEAE)}

RESUMO: A região da Zona da Mata está localizada no sudeste do estado de Minas Gerais, Brasil com fauna e flora diversificadas, incluindo insetos herbívoros e plantas Solanaceae. Lagartas Ithomiinae foram observadas danificando árvore de Solanum granulosoleprosum Dunal (Solanaceae), usada para diversos fins e abundante em floresta secundária. Objetivou-se, com este estudo, identificar lagartas desfolhadoras de S. granuloso-leprosum no campus da Universidade Federal de Viçosa (UFV) em Viçosa, Minas Gerais, Brasil e revisar plantas hospedeiras de Mechanitis polymnia (L., 1758) (Lepidoptera: Nymphalidae). Treze lagartas encontradas danificando uma árvore de S. granuloso-leprosum no campus da UFV foram coletadas e mantidas no Laboratório de Controle Biológico de Insetos (LCBI) da UFV até a emergência de adultos. Essas lagartas foram de duas espécies, sendo dez da primeira e três da segunda espécie. Espécimes adultos da última espécie foram identificados como Ithomia lichyi lichyi D’Almeida, 1939 (Lepidoptera: Nymphalidae) no Departamento de Zoologia da Universidade Federal do Paraná (UFPR) em Curitiba, Paraná, Brasil e do grupo de dez lagartas como Mechanitis polymnia casabranca Haensch, 1905 (Lepidoptera: Nymphalidae) no Museu de Zoologia da Universidade de São Paulo (USP) em São Paulo, Brasil. Esse é o primeiro relato de M. polymnia casabranca e I. lichyi lichyi juntos, danificando planta de S. granuloso-leprosum, na região da Zona da Mata, de Minas Gerais, Brasil e 57 plantas estão registradas como hospedeiras de M. polymnia.

Palavras-chave: Danos, Ithomiinae, Papilionoidea, Solanales, Zona da Mata

\section{INTRODUCTION}

The Zona da Mata region, located in the southeastern Minas Gerais State, Brazil, with $36.058 \mathrm{~km}^{2}$, representing $6.2 \%$ of the area of Mata Atlântica biome in this state (RESENDE et al., 2009). Its native vegetation was formed by Floresta Tropical, with dense tree cover and as an expansion of the Mata Atlântica (PORTUGAL et

\footnotetext{
${ }^{1}$ Universidade Federal de Viçosa - Viçosa, Minas Gerais, Brasil

${ }^{2}$ Instituto Federal Goiano - Urutaí, Goiás, Brasil

${ }^{3}$ Universidade Federal do Paraná - Curitiba, Paraná, Brasil
}

al., 2010). These forests were reduced to small patches and bushes on steep slopes and replaced, largely, by agricultural crops, pasture and reforestation (SOUZA et al., 2009). The precipitation of the Zona da Mata varies from 1,200 to $1,400 \mathrm{~mm}$ (REIS et al., 2007). The tropical climate has hot summers, temperatures reaching $25{ }^{\circ} \mathrm{C}$ and low temperatures at altitudes of $1,000 \mathrm{~m}$ above sea level (SANTANA et al., 2010). The terrain is rugged, with 
predominance of hills and narrow valleys and mountains formed by ancient crystalline rocks. The altitude varies between $100 \mathrm{~m}$ in the Rio Pomba and Paraíba do Sul valleys and $1.889 \mathrm{~m}$ in the Pico do Brigadeiro (NUNES et al., 2009).

Solanum granuloso-leprosum Dunal (Solanaceae) is small tree and, in naturally occurring, reaches $12 \mathrm{~m}$ height and diameter at breast height of $30 \mathrm{~cm}$ (SOUZA; VALIO, 2001). This species occurs in secondary forests colonizing devastated areas, in northeastern Argentina, Uruguay, Paraguay and south-central Brazil (POUYUROJAS et al., 2006). Its wood is suitable for pulp and energy, its fruits enjoyed by wildlife and its leaves used as vermifuge for horses (FLORES-AYLAS et al., 2003; JACOMASSA; PIZO, 2010). The main interest in $S$. granuloso-leprosum is related to plantations for recovery of degraded ecosystems (FERREIRA et al., 2007).

The Ithomiinae (Lepidoptera: Nymphalidae) subfamily has, approximately, 370 species of butterflies (GIRALDO; URIBIE, 2010) and some feed on leaves of $S$. granuloso-leprosum, which may reduce the rate of photosynthesis and the development of this plant. These insects can be found in the Neotropical region from northern Argentina to Mexico (WILLMOTT; FREITAS, 2006) and abundant in tropical forests, including small fragments and urban and suburban systems (BROWN JUNIOR; FREITAS, 2003). Mechanitis species adapt to a wide variety of agricultural habitats and secondary forests where its caterpillars feed on host plants (YOUNG; MOFFETT, 1979). Ithomia species are abundant and with variable patterns of coloration of the wings, including transparent. These insects can mimic other genera of Lepidoptera, as Hypothyris, Napeogenes, Oleria and Scada (MALLARINO et al., 2004).

Caterpillars Mechanitis and Ithomia were reported in several countries on Solanum (Solanaceae) plants, with 24 host plants for Mechanitis polymnia casabranca Haensch, 1905 (Lepidoptera: Nymphalidae) (WILLMOTT; MALLET, 2004). Caterpillars of this species and of Mechanitis lysimnia lysimnia (F., 1793) (Lepidoptera: Nymphalidae) were found together in Itueta, Vale do Rio Doce region of Minas Gerais State, Brazil (VASCONCELLOS-NETO; BROWN JUNIOR, 1982) and the first in plants of S. granuloso-leprosum in São Paulo State, Brazil (DRUMMOND; BROWN JUNIOR, 1987). The occurrence of caterpillars of $M$. lysimnia lysimnia and Ithomia lichyi lichyi D'Almeida, 1939 (Lepidoptera: Nymphalidae) in plants of this Solanaceae was unknown in the Zona da Mata of Minas Gerais State. The objective of this work was to record the occurrence of M. polymnia casabranca and I. lichyi lichyi together damaging plant of S. granuloso-leprosum in the Zona da Mata region of Minas Gerais State, Brazil and review host plants of Mechanitis polymnia (L., 1758) (Lepidoptera: Nymphalidae).

\section{MATERIAL AND METHODS}

Thirteen caterpillars were found on April 22, 2011 damaging a plant with $4 \mathrm{~m}$ height of $S$. granulosoleprosum at the garden of the Pavilhão de Aulas (PVA I) from Universidade Federal de Viçosa (UFV) in Viçosa, Minas Gerais State, Brazil. This plant was identified after comparison with material deposited in the Laboratório de Dendrologia from UFV. These caterpillars were brought to the Laboratório de Controle Biológico de Insetos (LCBI) from UFV and placed in cage $(12.5 \mathrm{~cm}$ height $\times 12.5$ $\mathrm{cm}$ width $\times 30.5 \mathrm{~cm}$ length) with branches of this plant changed, daily, until the pupation. The stems of these branches were placed in glass tubes with water to reduce their leaves wilt. Adults from these caterpillars were fed with nutrient solution (10.5 g of honey, 1.051 of distilled water, $350 \mathrm{ml}$ of beer, $60.0 \mathrm{~g}$ of sucrose, $1.05 \mathrm{~g}$ of ascorbic acid and $1.05 \mathrm{~g}$ of Nipagin ${ }^{\circledR}$ ) moistened in cotton swab second proposed methodology for Anticarsia gemmatalis Hübner, 1818 (Lepidoptera: Noctuidae) (FERREIRA et al., 2008). Adult specimens were photographed and deposited in the LCBI from UFV. Photos of adults of the group of ten caterpillars were sent to the Museu de Zoologia of Universidade de São Paulo (USP) in São Paulo State, Brazil and the group of three, sending a female specimen to the Departamento de Zoologia of Universidade Federal do Paraná (UFPR) in Curitiba, Paraná State, Brazil, for identifies these insects. Host plants of M. polymnia were reviewed.

\section{RESULTS AND DISCUSSION}

Ten (Figure 1A - adult) and three (Figure 1B adult) caterpillars, respectively, belonged to two species. Individuals of the group of ten caterpillars become pupae after the fifth day of collection. Five normal adults and five deformed emerged from these pupae after the 12th day of pupation and the normal survived for 10 days. Adults of this group were identified as M. polymnia casabranca in the Museu de Zoologia of USP in São Paulo State, Brazil. Those of the group of three caterpillars become pupae after

Cerne, Lavras, v. 20, n. 1, p. 165-172, jan./mar. 2014 
the fifth day of collection. Two normal adults emerged from these pupae after the 12th day of pupation and survived by 10 days. These adults were identified as I. lichyi lichyi in the Departamento de Zoologia of UFPR in Curitiba, Paraná State, Brazil.

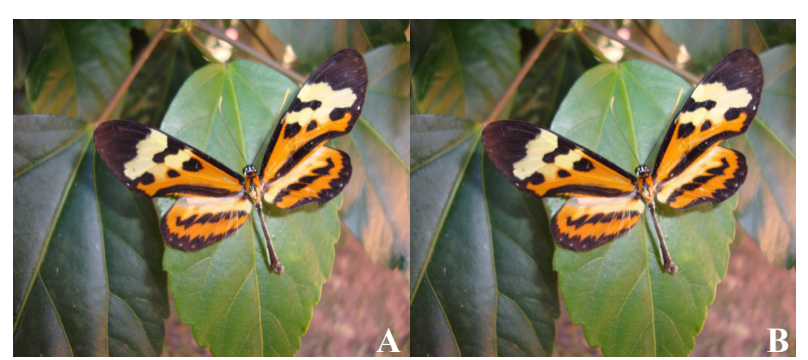

Figura 1 - Adultos de Mechanitis polymnia casabranca (A) e Ithomia lichy lichy (B) (Lepidoptera: Nymphalidae), respectivamente, repousando sobre uma folha artificial, coletados em Viçosa, Minas Gerais, Brasil após suas lagartas danificarem planta de Solanum granuloso-leprosum (Solanaceae).

Figure 1-Adults of Mechanitis polymnia casabranca (A) and Ithomia lichyi lichyi (B) (Lepidoptera: Nymphalidae), respectively, resting on an artificial leaf, collected in Viçosa, Minas Gerais State, Brazil after their caterpillars damaged plant of Solanum granuloso-leprosum (Solanaceae).

This is the first report of M. polymnia casabranca and I. lichyi lichyi damaging plant of S. granulosoleprosum in the Zona da Mata region of Minas Gerais State, Brazil. Ithomiinae common in southeastern Brazil (VASCONCELOS-NETO; BROWN JUNIOR, 1982) were, also, found in central Brazil after 24 years of the first assessment (EMERY et al., 2006), suggesting adaptation of these insects in different habitats. Insects of this group were not observed in 2004 and in some previous years, suggesting that the population dynamics of Ithomiinae may vary in different climatic years. For example, Hypothyris ninonia daeta Boisduval,1836 (Lepidoptera: Nymphalidae) was the most abundant butterfly in 2003, while M. polymnia was absent in that year, although the most abundant in 2004 (VASCONCELOS-NETO; BROWN JUNIOR, 1982).

The fact of two species of Ithomiinae were found in a same plant of $S$. granuloso-leprosum agrees with the observed for M. polymnia and Mechanitis lysimnia (F., 1793) (Lepidoptera: Nymphalidae) from central Mexico to southeastern Brazil on plants of Solanum spp. (VASCONCELOS-NETO; BROWN JUNIOR, 1982).
However, $M$. lysimnia was more tolerant to climate years with lower temperature and, therefore, its population spread to central Argentina, although it was absent in Bacia Amazônia Central (BROWN JUNIOR, 1977). However, these species lay eggs on host plants in Sumaré, São Paulo State, Brazil, and showed peaks of reproduction during the year, above of their caterpillars and adults have variations in the color of the body (VASCONCELOS-NETO; BROWN JUNIOR, 1982). Ithomiinae can coexist on the same host, because the extreme scarcity of a host plant in a spatial or temporal limit leads to acceptance of that most abundant (BROWN JUNIOR, 1977; VASCONCELOS-NETO; BROWN JUNIOR, 1982). In addition, Ithomiinae species with mimetic features similar can mate and reproduce after stimulation by pheromone (SCOTT, 1973).

A total of 57 host plant species was recorded for M. polymnia (Table 1). Economically important plants, cultivated by man, as Lycopersicun esculetum Mill (Solanaceae) are hosts of M. polymnia, suggesting that the devastation of the Mata Atlântica biome may make this species a potential pest in crops of plants of this family (DRUMMOND; BROWN JUNIOR, 1987; FREITAS, 1996; SILVA et al., 1968). The polyphagia of M. polymnia makes this species most adaptable to coexistence with other Ithomiinae in a same plant and the use of host species of Solanaceae plants, abundant in the Zona da Mata region of Minas Gerais State, Brazil, could increase their survival (FERREIRA et al., 2007).

The behavior of caterpillars of $M$. polymnia casabranca and I. lichyi lichyi was gregarious on plant of S. granuloso-leprosum. Five caterpillars of the first species and three of the second were together on the adaxial side on a same leaf of $S$. granuloso-leprosum. Five caterpillars of M. polymnia casabranca were in another leaf of plant of this Solanaceae. The gregariousness in Ithomiinae is an adaptation to adverse conditions of the dry season, as high temperatures and low relative humidity of air (PINHEIRO et al., 2008). The caterpillars were fed on leaves of S. granuloso-leprosum, with preference for those younger, but leaving the veins intact. Natural enemies of these caterpillars were not observed. Generalist predator ant Camponotus crassus Mayr, 1862 (Hymenoptera: Formicidae) prey Ithomiinae, but individuals of this family can produce chemical defenses, for example, toxic or nonpalatable substances, to avoid predation by natural enemies (PORTUGAL; TRIGO, 2005).

Cerne, Lavras, v. 20, n. 1, p. 165-172, jan./mar. 2014 
Tabela 1 - Plantas hospedeiras de lagartas de Mechanitis polymnia (Lepidoptera: Nymphalidae) e referências.

Table 1 - Host plants of caterpillars of Mechanitis polymnia (Lepidoptera: Nymphalidae) and references.

\begin{tabular}{|c|c|}
\hline Host plants & References \\
\hline \multicolumn{2}{|l|}{ Solanaceae } \\
\hline Brugmansia candida & Brazil: (SILVA et al., 1968) \\
\hline $\begin{array}{l}\text { Brunfelsia grandiflora } \\
\text { Cyphomandra spp. }\end{array}$ & $\begin{array}{l}\text { Brazil: (SILVA et al, } 1968) \\
\text { Neotropical: (LAMAS, } 1985 \text { ) }\end{array}$ \\
\hline Cyphomandra betaceae & Brazil: (BIZARRO et al., 2003; SILVA et al., 1968) \\
\hline $\begin{array}{l}\text { cyphomanara corymbifiora } \\
\text { Cyphomandra diploconos }\end{array}$ & Brazil: (DRUMMOND; BROWN JUNIOR, 1987) (spp. casabranca)] \\
\hline $\begin{array}{l}\text { Cyphomandra fragrans } \\
\text { Cyphomandra hartwegii }\end{array}$ & $\begin{array}{l}\text { Brazil: (PORTUGAL; TRIGO, 2005) } \\
\text { Ecuador:(DRUMMOND: BROWN JUNIOR, 1987) (spn dorissides)] }\end{array}$ \\
\hline Cyphomandra sciadostylis & Brazil: (DRUMMOND; BROWN JUNIOR, 1987) (spp. casabranca); (BIZARRO et al., 2003] \\
\hline $\begin{array}{l}\text { Cyphomandra velutina } \\
\text { Datura stramonium }\end{array}$ & $\begin{array}{l}\text { Brazil: (SILVA et al, 1968) (spp casabranca) (DRUMMOND; BROWN JUNIOR, 1987) } \\
\text { Venezuela: (GUAGLUMI } 1971 \text { (spo veritabilis) }\end{array}$ \\
\hline Jaltomata procumbens & Costa Rica: (HABER, 1978) (spp. isthmia) \\
\hline $\begin{array}{l}\text { Lycopersicon sp. } \\
\text { Lycopersicon esculentum }\end{array}$ & $\begin{array}{l}\text { Brazil: (FREITAS, 1996) (spp; casabranca) } \\
\text { Brazil: (DRUMMOND; BROWN JUNIOR, 1987; SILVA et al., 1968) (spp. casabranca); Ecuador: }\end{array}$ \\
\hline Nicotiana tabacum & $\begin{array}{l}\text { (DRUMMOND; BROWN JUNIOR, 1987) (spp dorissides) } \\
\text { Venezuela: (GUAGLIUMI 1971) (spp. veritabilis) }\end{array}$ \\
\hline Solanum sp. & Brazil: (BIZARRO et al., 2003; FREITAS, 1996;) Colombia: (OROZCO et al., 2009) \\
\hline Solanum sp. (section Brevantherum) & Brazil: (DRUMMOND; BROWN JUNIOR, 1984) (spp. polymnia)]; Peru: (DRUMMMOND; BROWN \\
\hline Solanum sp. (section Solan & $\begin{array}{l}\text { JUNIUR, (198) Spp. eurydice) } \\
\text { Ecuador: (DRUM JUNIOR, 1987) (spp. dorissides)] }\end{array}$ \\
\hline Solanum sp. (subgenus $L$ & $\begin{array}{l}\text { Brazil: (DRUMMOND; BROWN JUNIOR, 1987) (spp. polymnia) (spp. casabranca)]; Trinidad: } \\
\text { (DRUMMOND. BROWN JUNIOR 1987) (snp. kayei) }\end{array}$ \\
\hline Solanum spp. & Brazil: (BROWN JUNIOR, 1992) (spp. casabranca); (PINHEIRO et al., 2008) (spp. casabranca); \\
\hline & $\begin{array}{l}\text { Costa Rica: (YOUNG, 1984) (spp. isthmia); N } \\
\text { 1970) (spp. kavei); n.i.: (NISHIDA, 2002) }\end{array}$ \\
\hline $\begin{array}{l}\text { Solanum aculeatissimun } \\
\text { Solanum adenotrichum }\end{array}$ & Brazil: (SILVA et al., 1968); Suriname: (DRUMMOND; BROWN JUNIOR, 1987) (spp. polymnia) \\
\hline $\begin{array}{l}\text { Solanum adenotrichum } \\
\text { Solanum adhaerens }\end{array}$ & $\begin{array}{l}\text { Brazil: (DRUMMOND; BROWN JUNIOR, 1987) (spp. casabranca) } \\
\text { Costa Rica. (GENTRY; DYER 2002) (snn, isthmia)] }\end{array}$ \\
\hline Solanum asperum & 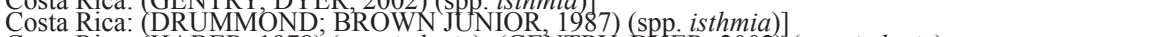 \\
\hline $\begin{array}{l}\text { Solanum aturense } \\
\text { Solanum crinitum }\end{array}$ & Costa Rica: (HABER, 1978) (spp isthmia); (GENTRY; DYER, 2002) (spp. isthmia) \\
\hline $\begin{array}{l}\text { Solanum crinutum } \text { Solanum goodpeedii } \\
\text { Solan }\end{array}$ & $\begin{array}{l}\text { Brazll: (DRUMMOND; } \\
\text { Bolivia:(DRUMMOND; BROWN JUNIOR, 1987) (spp. angustifascia) }\end{array}$ \\
\hline Solanum granuloso-leprosum & Brazil: (DRUMMOND; BROWN JUNIOR, 1987) (spp. casabranca) \\
\hline Solanum hazenii & $\begin{array}{l}\text { Costa Rica: (JANZEN; HALLWACHS, 2012) (spp. isthmia) } \\
\text { Costa Rica: (JANZEN; HALLWACHS, 2012) (spp. isthmia) }\end{array}$ \\
\hline Solanum hexandrum & Brazil: (COSTA, 1999 ) (spp. casabranca) \\
\hline Solanum hispidum & $\begin{array}{l}\text { Venezuela: (DRUMMOND; BROWN JUNIOR, 1987) (spp. veritabilis) } \\
\text { Costa Rica: (DRUMMOND; BROWN JUNIOR, } 1987 \text { (spp. isthmia) }\end{array}$ \\
\hline $\begin{array}{l}\text { Solanum incarceratum } \\
\text { Solanum jamaicense }\end{array}$ & $\begin{array}{l}\text { Brazil: (DRUMMOND; BROWN JUNIOR, 1987; SILVA et al., 1968) (spp. casabranca) } \\
\text { Colombia: (GIRALDO; URIBIE, 2010); Costa Rica: (DRUMMOND; BROWN JUNIOR, 1987) (spp. }\end{array}$ \\
\hline Solan & $\begin{array}{l}\text { isthmia) } \\
\text { Brazil: (COSTA, 1999) (spp. casabranca) }\end{array}$ \\
\hline $\begin{array}{l}\text { Solanum mammosum } \\
\text { Solanum mauritianum }\end{array}$ & 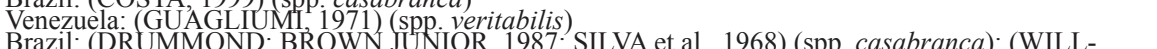 \\
\hline & $\begin{array}{l}\text { BrazI: (DRUIVIVIUND; BRUWN JUNIUR, 198/; SILVA et al., 1968) (spp. casabranca, } \\
\text { MOTT; MALLET, 2004) }\end{array}$ \\
\hline Solanum megalochiton & Brazil:'(DRUMMÓND; BROWN JUN \\
\hline Solanum melongena & Brazil:(DRUMMOND; BROWN JUNIOR, 1987) (spp. casabranca) \\
\hline & Venezuela:(DRUMMOND; BROWN JUNIOR, 1987) (spp. veritabilis) \\
\hline $\begin{array}{l}\text { Solanum palinacanthum } \\
\text { Solanum paniculatum }\end{array}$ & $\begin{array}{l}\text { Brazil: (COSTA, 1999) (spp. casabranca) } \\
\text { Brazil: (DRUMMOND; BROWN JUNIOR, 1987; SILVA et al., 1968) (spp. casabranca) }\end{array}$ \\
\hline Solanum quitoense & Colombia: (GALLEGO, 1950) (spp. caucaensis); Ecuador: (DRUMMOND; BROWN JUNIOR, 1987) \\
\hline Solanum robustum & Brazil: (DRUMMOND; BROWN JUNIOR, 1987) (spp. casabranca) \\
\hline Solanum $r$ & n.i.: (CHAPMAN; HALL, 1993); Costa Rica: (HABER, 1978) (spp. isthmia); (DRUMMOND; \\
\hline Solanum rugosum & Costa Rica: (HABER, 1978) (spp. isthmia)]; Ecuador: (BECCALONI, 1997) (spp. dorissides) \\
\hline Solanum schlechtendalianum & Costa Rica: (DRUMMOND; BROWN JUNIOR, 1987) (spp. isthmia); (JANZEN; HALLWACHS, \\
\hline Solanum & $\begin{array}{l}\text { 2012)(spp isthmia) } \\
\text { Brazil: (DRUMMOND; BROWN JU }\end{array}$ \\
\hline Solanum se & $\begin{array}{l}\text { Brazil: (SILVA et al., 1968) (spp. dorissides); (DRUMMOND; BROWN JUNIOR, 1987) (spp. } \\
\text { casabranca); Ecuador: (DRUMMOND; BROWN JUNIOR, 1987) (spp. dorissides)]; Peru: (LAMAS, }\end{array}$ \\
\hline & 1976) (spp. dorissides); Venezuela: (DRUMMOND; BROWN JUNIOR, 1987) (spp. veritabilis) \\
\hline Solanum sissiliflorum & Brazil: (SILVA et al., 1968) (spp. dorissides); (DRUMMOND; BROWN JUNIOR,, 1987) (spp. \\
\hline & \\
\hline Solanum sisymbriifolium & Brazịl: (SILVA et al., 1968; DRUMMOND; BROWN JUNIOR, 1987) (spp. polymnia) \\
\hline $\begin{array}{l}\text { Solanum spin } \\
\text { Solanum stran }\end{array}$ & $\begin{array}{l}\text { Brazil: (SILVA et al., 1968) } \\
\text { Brazil: (DRUMMOND. BROWN Ju }\end{array}$ \\
\hline Solanum tabacifolium & Brazil: (BRUCKMANN et al., 2000) (spp. casabranca); (PORTUGAL; TRIGO, 2005) (spp. casabran- \\
\hline Solanum torvum & $\begin{array}{l}\text { ca) } \\
\text { Belize: (MEERMAN, 2003) (spp. lycidice); Brazil: (DRUMMOND; BROWN JUNIOR, 1987) (spp. } \\
\text { casabranca)]; Colombia: (CONSTANTINO, 1998) (spp. caucaensis); Costa Rica: (DEVRIES, 1987) }\end{array}$ \\
\hline m t th brocum ondi & $\begin{array}{l}\text { (spp. isthmia); Venezuela:(GUAGLIUMI, 1971).(spp. veritabilis) } \\
\text { Venezuela: (GUAGLIUMI, 1971) (spp. veritabilis) }\end{array}$ \\
\hline & $\begin{array}{l}\text { Brazil: (SILVA et al., 1968) (spp. casabranca); (DRUMMOND; BROWN JUNIOR, 1987) (spp. casa- } \\
\text { branca): (FREITAS. 1996) (spp. casabranca) }\end{array}$ \\
\hline
\end{tabular}

Cerne, Lavras, v. 20, n. 1, p. 165-172, jan./mar. 2014 


\section{CONCLUSIONS}

Mechanitis polymnia casabranca and I. lichyi lichyi have potential of defoliation and complete the life cycle on plants of S. granuloso-leprosum in the field and laboratory. Despite of the large number of hosts of M. polymnia, further studies should be conducted to evaluate the mechanisms of coexistence between these two species.

\section{ACKNOWLEDGEMENTS}

To Dr. Marcelo Duarte da Silva to identify Mechanitis polymnia casabranca Haensch, 1905 (Lepidoptera: Nymphalidae). To "Conselho Nacional de Desenvolvimento Científico e Tecnológico (CNPq)", "Coordenação de Aperfeiçoamento de Pessoal de Nível Superior (CAPES)", and "Fundação de Amparo a Pesquisa do Estado de Minas Gerais (FAPEMIG)" for financial support.

\section{REFERENCES}

BARCANT, M. Butterflies of Trinidad and Tobago. London: Collins, 1970.

BECCALONI, G. W. Vertical stratification of ithomiine butterfly (Nymphalidae: Ithomiinae) mimicry complexes: the relationship between adult flight height and larval host plant height. Biological Journal of the Linnean Society, Southampton, v. 62, n. 3, p. 313-341, Nov. 1997.

BIZARRO, J. M. F.; CASAGRANDE, M. M.; MIELKE, O. H. H. External morphology of Thyridia psidii cetoides (Rosenberg \& Talbot): III., abdomen and appendages (Lepidoptera, Nymphalidae, Ithomiinae).

Revista Brasileira de Zoologia, Curitiba, v. 20, n. 4, p. 681-684, Dec. 2003.

BROWN JUNIOR, K. S. Borboletas da Serra do Japi: diversidade, hábitats, recursos alimentares e variação temporal. In: MORELLATO, L. P. C. (Ed.). História natural da serra do Japi: ecologia e preservação de uma área florestal no sudeste do Brasil. Campinas: UNICAMP, 1992. p. 142-187.

BROWN JUNIOR, K. S. Geographical patterns of evolution in Neotropical Lepidoptera: differentiation of the species of Melinaea and Mechanitis (Nymphallidae, Ithomiinae). Systematic Entomology, Canberra, v. 2, n. 3, p. 161-197, July 1977.

BROWN JUNIOR, K. S.; FREITAS, A. V. L. Butterfly communities of urban forest fragments in Campinas, São Paulo, Brazil: structure, instability, environmental correlates, and conservation. Journal of Insect Conservation, Headington, v. 6, n. 4, p. 217-231, Dec. 2003.

BRÜCKMANN, M.; TRIGO, J. R.; FOGLIO, M. A.; HARTMANN, T. Storage and metabolism of radioactively labeled pyrrolizidine alkaloids by butterflies and larvae of Mechanitis polymnia (Lepidoptera: Nymphalidae, Ithomiinae).

Chemoecology, Brussels, v. 10, n. 1, p. 25-32, Mar. 2000.

BUZENYA, Z. R.; HALL, J. B. Six cultivars of Solanum macrocarpon (Solanaceae) in Ghana. Bothalia, Pretoria, v. 17, n. 1, p. 91-95, July 1987.

CHAPMAN, E.; HALL, W. Caterpillars: ecological and evolutionary constraints on foraging. New York: Wiley, $1993.587 \mathrm{p}$.

CONSTANTINO, L. M. Butterfly life history studies, diversity, ranching and conservation in the Chocó rain forests of Western Colombia (Insecta: Lepidoptera). SHILAP Revista de Lepidopterologia, Madrid, v. 26, n. 101, p. 19-39, Jan. 1998.

COSTA, F. A. P. L. New records of larval hostplants for Ithomiinae butterflies (Nymphalidae). Revista Brasileira de Biologia, São Carlos, v. 59, n. 3, p. 455459, Aug. 1999.

DEVRIES, P. J. The butterflies of Costa Rica and their natural history: Papilionidae, Pieridae, Nymphalidae. Princeton: Princeton University, 1987. $456 \mathrm{p}$.

DRUMMOND, B. A.; BROWN JUNIOR, K. S. Ithomiinae (Lepidoptera: Nymphalidae): summary of know larval food plants. Annals of the Missouri Botanical Garden, Missouri, v. 74, n. 2, p. 341-358, Jan. 1987.

EMERY, E. O.; BROWN JUNIOR, K. S.; PINHEIRO, C. E. G. As borboletas (Lepidoptera, Papilionoidea) do Distrito Federal, Brasil. Revista Brasileira de

Cerne, Lavras, v. 20, n. 1, p. 165-172, jan./mar. 2014 
Entomologia, Curitiba, v. 50, n. 1, p. 85-92, jan./mar. 2006.

FERREIRA, J. A. M.; ZANUNCIO, J. C.; TORRES, J. B.; MOLINA-RUGAMA, A. J. Predatory behaviour of Podisus nigrispinus (Heteroptera: Pentatomidae) on different densities of Anticarsia gemmatalis (Lepidoptera: Noctuidae) larvae. Biocontrol Science and Technology, Lethbridge, v. 18, n. 7, p. 711-719, July 2008.

FERREIRA, R. A.; DAVIDE, A. C.; BEARZOTI, E.; MOTTA, M. S. Tree species direct sowing for forest restoration. Cerne, Lavras, v. 13, n. 3, p. 271-279, jul./set. 2007.

FLORES-AYLAS, W. W.; SAGGIN, O. J.; SIQUEIRA, J. O.; DAVIDE, A. C. Effects of Glomus etunicatum and phosphorus on initial growth of woody species at direct seeding. Pesquisa Agropecuária Brasileira, Brasília, v. 38, n. 2, p. 257-266, fev. 2003.

FREITAS, A. V. L. Population biology of Heterossais edessa (Nymphalidae) and its associated Atlantic Forest Ithomiinae community. The Journal of the Lepidopterists' Society, Eureka, v. 50, n. 1, p. 273-289, Dec. 1996.

GALLEGO, F. L. Estudios entomológicos. Revista Facultad Nacional de Agronomia, Medellin, v. 11, n. 37, p. 57-71, ene. 1950 .

GENTRY, G. L.; DYER, L. A. On the conditional nature of Neotropical caterpillar defenses against their natural enemies. Ecology, Davis, v. 83, n. 11, p. 3108-3119, Nov. 2002.

GIRALDO, C. E.; URIBIE, S. I. Record of Mechanitis polymnia (Lepidoptera: Ithomiinae) on Solanum jamaicense and life cycle in the laboratory. Revista Colombiana de Entomologia, Bogotá, v. 36, n. 1, p. 165168, jun. 2010.

GUAGLIUMI, P. Entomofauna della canna da zucchero nel Nord-Est del Brasile. Rivista di Agricoltura Subtropicale e Tropicale, Firenze, v. 65, n. 4, p. 49-66, 1971.

HABER, W. A. Evolutionary ecology of tropical mimetic butterflies (Lepidoptera: Ithomiinae). 1978. $454 \mathrm{f}$. Thesis (Ph.D. in Entomology) - University of Minnesota, Minneapolis, 1978.

JACOMASSA, F. A. F.; PIZO, M. A. Birds and bats diverge in the qualitative and quantitative components of seed dispersal of a pioneer tree. Acta Oecologica, Paris, v. 36, n. 5, p. 493-496, Sept./Oct. 2010.

JANZEN, D. H.; HALLWACHS, W. Philosophy, navigation and use of a dynamic database (ACG Caterpillars SRNP) for an inventory of the macrocaterpillar fauna, and its food plants and parasitoids, of the Area de Conservacion Guanacaste (ACG), northwestern Costa Rica. Disponível em: $<$ http://janzen.sas.upenn.edu>. Acesso em: 10 fev. 2012.

LAMAS, G. Los Papilionoidea (Lepidoptera) de la zona reservada de Tambopata, Madre de Dios, Perú: I., Papilionidae, Pieridae y Nymphalidae. Revista Peruana de Entomologia, Lima, v. 27, n. 1, p. 59-73, ene. 1985.

LAMAS, G. Taxonomia e evolução dos gêneros Ituna Doubleday (Danainae) e. Paititia gen. n., Thyridia Hübner e Methona Doubleday (Ithomiinae) (Lepidoptera, Nymphalidae). 1973. 255 f. Tese (Doutorado em Zoologia) - Universidade de São Paulo, São Paulo, 1973.

MALLARINO, R.; BERMINGHAM, E.; WILLMOTT, K. R.; WHINNETT, A.; JIGGINS, C. D. Molecular systematics of the butterfly genus Ithomia (Lepidoptera: Ithomiinae): a composite phylogenetic hypothesis based on seven genes. Molecular Phylogenetics and Evolution, Detroit, v. 34, n. 3, p. 625-644, Mar. 2004.

MEERMAN, J. C. REA: mayflower bocawina national park: appendices. Dangriga: PACT, 2003. v. 2, 44 p.

NISHIDA, R. Sequestration of defensive substances from plants by Lepidoptera. Annual Review of Entomology, Palo Alto, v. 47, n. 1, p. 47-57, Jan. 2002.

NUNES, L. A. P. L.; DIAS, L. E.; JUCKSCH, I.; BARROS, N. F.; KASUYA, M. C. M.; CORREIA, M. E. F. Impact of monocultivation coffee on biological indicators of quality soil in the Zona da Mata (MG), Brazil. Ciência Rural, Santa Maria, v. 39, n. 9, p. $2467-$ 2474, out. 2009.

OROZCO, S.; MURIEL, S. B.; PALACIO, J. Diversity of diurnal Lepidoptera in an area of tropical dry forest from west of Antioquia. Actualidades Biológicas, Medellín, v. 31, n. 90, p. 31-41, jun. 2009.

PINHEIRO, C. E. G.; MEDRI, Í. M.; SALCEDO, A. K. M. Why do the ithomiines (Lepidoptera, Nymphalidae)

Cerne, Lavras, v. 20, n. 1, p. 165-172, jan./mar. 2014 
aggregate?: notes on a butterfly pocket in central Brazil. Revista Brasileira de Entomologia, Curitiba, v. 52, n. 4, p. 610-614, jan. 2008.

PORTUGAL, A. F.; COSTA, O. D. V.; COSTA, L. M. Physical and chemical properties of a soil under different production systems and forest in the Zona da Mata region of Minas Gerais State, Brazil. Revista Brasileira de Ciência do Solo, Viçosa, v. 34, n. 2, p. 575-585, mar./abr. 2010.

PORTUGAL, A. H. A.; TRIGO, J. R. Similarity of cuticular lipids between a caterpillar and its host plant: a way to make prey undetectable for predatory ants? Journal of Chemical Ecology, Tampa, v. 31, n. 11, p. 2551-2561, Nov. 2005.

POUYU-ROJAS, E.; SIQUEIRA, J. O.; SANTOS, J. G. D. Symbiotic compatibility of arbuscular mycorrhizal fungi with tropical tree species. Revista Brasileira de Ciência do Solo, Viçosa, v. 30, n. 3, p. 413-424, maio/jun. 2006.

REIS, H.; SCOLFORO, J. R. S.; OLIVEIRA, A. D.; OLIVEIRA, A. T.; MELLO, J. M. Floristic composition analysis, diversity and similarity of Atlantic Forest fragments in Minas Gerais State, Brazil. Cerne, Lavras, v. 13, n. 3, p. 280-290, set. 2007.

RESENDE, J. L. P.; PADUA, C. T. J.; OLIVEIRA, A. D.; SCOLFORO, J. R. S.; COELHO, L. M. Characterization of a forest incentive program in Minas Gerais State. Cerne, Lavras, v. 15, n. 3, p. 295-302, jul./set. 2009.

SANTANA, S. W. J.; BARROS, R.; TORRES, J. B.; GONDIM, M. G. C. Thermal requirements of the coconut pest Atheloca subrufella (Hulst) (Lepidoptera: Phycitidae). Neotropical Entomology, Londrina, v. 39, n. 2, p. 181-186, Mar./Apr. 2010.

SCOTT, J. A. Mating of butterflies. The Journal of Research on the Lepidoptera, Columbia, v. 11, n. 1, p. 99-127, Jan. 1973.

SILVA, A. G. D. A. E.; GONÇALVES, C. R.; GALVÃO, D. M.; GONÇALVES, A. J. L.; GOMES, J.; SILVA, M. N.; SIMONI, L. Quarto catálogo dos insetos que vivem nas plantas do Brasil: seus parasitos e predadores. Rio de Janeiro: Ministério da Agricultura, 1968. 622 p.

SOUZA, R. P.; VALIO, I. F. M. Seed size, seed germination, and seedling survival of Brazilian tropical tree species differing in successional status. Biotropica, Zurich, v. 33, n. 3, p. 447-457, Mar. 2001.

SOUZA, R. M.; ANJOS, N.; SORGATO, J. C.

Occurrence of Naupactus cervinus (Boheman) in coffee plantation in the region of Zona da Mata mineira. Ciência e Agrotecnologia, Lavras, v. 33, n. 1, p. 1967-1971, jan./ fev. 2009.

VASCONCELLOS-NETO, J.; BROWN JUNIOR, K. S. Interspecific hybridization in Mechanitis butterflies (Ithomiinae): a novel pathway for the breakdown of isolating mechanisms. Biotropica, Zurich, v. 14, n. 4, p. 288-294, Dec. 1982.

WILLMOTT, K. R.; FREITAS, A. V. Higher-level phylogeny of the Ithomiinae (Lepidoptera: Nymphalidae): classification, patterns of larval host plant colonization and diversification. Cladistics, New York, v. 22, n. 4, p. 297-368, Aug. 2006.

WILLMOTT, K. R.; MALLET, J. Correlations between adult mimicry and larval host plants in Ithomiine butterflies. Proceedings of the Royal Society B-Biological Sciences, London, v. 271, n. 1, p. 266-269, Aug. 2004.

YOUNG, A. M. Ithomiine butterflies associated with nonantbird droppings in Costa Rican tropical rain forest. The Journal of the Lepidopterists' Society, Eureka, v. 38, n. 1, p. 61-63, Dec. 1984.

YOUNG, A. M.; MOFFETT, M. Studies on the population biology of the tropical butterfly Mechanitis isthmia in Costa Rica. The American Midland Naturalist, Notre Dame, v. 101, n. 2, p. 309-319, Apr. 1979.

Recebido: 2 de fevereiro de 2012; aceito: 21 de agosto de 2013.

Cerne, Lavras, v. 20, n. 1, p. 165-172, jan./mar. 2014 
